\title{
ACCRUAL REVERSALS AND COMPANY PERFORMANCE: ANALYSIS OF EMERGING MARKET
}

\author{
Muhammad Saad Baloch \& Arshad Hassan
}

\begin{abstract}
This is a pioneering study on total accrual reversals, i.e. long-term reversals and their role in company performance in an emerging market. This study observes the impact of total accrual reversals on company performance more exclusively. The sample consists of 100 non-financial companies listed on the Pakistan Stock Exchange (PSE). The purpose is to examine the role of long-term reversals in the performance of companies by observing the impact of total accrual reversals for the current period as well as the previous period on the earnings as it is used as a proxy for company performance. The Pooled OLS Robust method with Driscoll-Kraay standard errors is used. The result indicates that total accrual reversals of the previous and current period affect the earnings of companies positively. This result rejects the perception that accrual reversal does not predict the earnings in the long-term perspective. The study concludes that the role of reversals of total accruals in the performance of companies is positive, which is beneficial for growing companies in an emerging market. Hence, companies should increase the total accrual reversals to enhance their performance and attract foreign investors.
\end{abstract}

Keywords: Accrual Reversals, Earnings, Emerging market, Pakistan Stock Exchange JEL Classification: M40, M41

\section{Introduction}

Company performance is the focus point for stakeholders. Companies perform different decisions like earnings management, the announcement of dividend policies, and specific capital structure policies, to enhance their performance to capture the market. Mostly, companies use earnings management techniques to obtain the desired results. Earnings management is a legal process in which companies manipulate their earnings to produce the required financial results that favour their business activities. Companies adopt these policies to lessen the volatility of the income, enhance the company performance and to fulfil the investor's expectations. Although it is a legal practice under the well-defined accounting rules, morally it is debatable because companies manipulate their actual earnings and report manipulated figures in financial reports to make these

Corresponding author: Muhammad Saad Baloch is currently pursuing his $\mathrm{PhD}$ at the Department of Management Sciences, COMSATS Institute of Information \& Technology, 45550, Islamabad, Pakistan. Email: msaad.baloch@gmail.com.

Arshad Hassan is Professor and Dean at the Department of Management and Social Sciences, Faculty of Management and Social Sciences, Capital University of Science and Technology, 45550, Islamabad, Pakistan. Email: aarshad.hasan@gmail.com. 
attractive for the investors and other stakeholders. Certain techniques exist like the cookie jar reserves, big bath, operating activities, depreciation and amortization and derivatives, which can be used in the earnings management process. Generally, companies use discretionary accruals for the earnings management process. Existing research identifies different models for detecting earnings management, such as the Modified Jones model, Jones model, DeAngelo model and the Healy model. Thus, the role of earnings management is critical in the financial accounting system. It only works in the accrual based accounting system, as it is not possible in the cash centred accounting system. Healy (1985) and Sloan (1996) identified the procedure of managing the earnings via the use of accruals and the reversal of accruals. In this period of competitiveness, it is essential for companies to compete and stay in the market by performing well, and their earnings must be consistent and smooth over the period. Companies make critical decisions concerning earnings management by using accrual reversals and to avoid taxation on profit and smoothing the profit over time.

Accrual based transactions are recorded when these take place. In this accounting system, the financial effect of a transaction takes place in the current period, but the involvement of cash is deferred to the next period. Economic events are recognized by matching the revenues of companies to their expenses of the current period when transactions take place instead of when cash is paid or received. Accruals can be calculated either by using the balance sheet approach or the cash flow approach, i.e. net income approach. Accruals contain the anticipation of possible future obligations like future cash outflows in the case of accrued expenses and liabilities, and also generate future benefits like future cash inflows in the case of accrued revenues. Therefore, the financial effects of this specific accounting system arise in the current period instead of when the associated benefits and costs are recognized. The advantage of accrual business transactions is that companies can perform their operations consistently even if there is a lack of cash. Thus, the accrual based system provides easiness to the running of a business. In the present era, when the world is like a global village, globalization increases the trade across the borders enormously.

The accrual reversals occur when their associated economic cost and benefits are acknowledged. These reversals should not have any influence on earnings. This means that forecasting economic benefits and actual economic benefits should be the same. However, in reality, these reversals do affect the earnings as a difference exists between the predicted and realized economic benefits. The reason for this difference may be the existence of estimation errors in the estimation method of accrual and requires accounting treatment to remove the gap. These estimation errors in the accruals and their linked reversals should be random if the accruals are considered to be unbiased estimators of future benefits, but that is not the case, as many studies have observed the impact of accruals on the earnings. Allen et al. (2013) showed the consequential reversals of inventory accruals with high frequency, which are demonstrated by inventory write-downs; such reversals impact the future earnings. Healy (1985) and Teoh 
et al. (1998) indicated accrual reversals in two periods, and, after two periods, these became insignificant. Long-term accrual reversals (Total Accrual Reversals) imply that companies may either experience positive reversals, which increase their earnings, or they may experience negative reversals, which lead to a decrease in their earnings. Total accrual reversals are a greater concern for the growing companies in emerging markets as the focus of companies is more on long-term decisions. Company performance can be determined through bookbased earnings, i.e. net income (EBIT). This has two factors, cash and accruals. Accruals are negatively linked with the persistence of earning rather than the cash flow. Some earlier studies identify that accruals are considered as being a faster means of reverting than cash flows. The reason may be the extreme accrual reversals as identified by Allen et al. (2013), because they reverse faster than normal accruals. Due to these reversals, accruals predict earnings as well as stock returns either negatively (Sloan, 1996) or positively (Hirshleifer et al., 2009; Baloch, 2015). Thus, the role of accrual reversals is crucial.

This study focuses on companies in Pakistan. As per the report of the Financial Times Stock Exchange (September, 2015), Pakistan's economy is considered to be an emerging market. This announcement attracts the attention of foreign investors. The main reason of getting investor's attention is the consistent pivotal performance of the Pakistan Stock Exchange (PSE) over the period of time. The behaviour of company management is different compared to the behaviour of developed markets in the shape of corporate governance and earnings management decisions. Even in the case of the global financial crisis of 2008 , this market suffered less compared to regional stock markets as well as developed stock markets. Because of its great importance, a few studies discuss whether the behaviour of investors in PSE is similar to the behaviour of investors in developed markets, and whether or not the performance of companies is affected by accrual reversals. As companies are growing it is necessary to see whether the components of accruals related to growth behave differently in an emerging market and what crucial role total accrual reversals play in determining company performance compared to developed markets where the role of current accruals and discretionary accruals have been discussed in previous studies. Nowadays emerging markets are more attractive for local as well as international investors due to their volatile nature and greater potential to absorb investment and give high returns compared to developed markets. Hence, it is a worthwhile contribution to explore the role of total accrual reversals in determining company performance in emerging markets so that stakeholders have a better picture to understand the growth phenomenon of companies and make decisions accordingly. Thus, this motivation led to the interest to conduct this study.

Most studies use the balance sheet method to measure accruals, which contains the possibility of errors, as identified by Hribar and Collins (2002). They demonstrated that research findings should be revisited using the cash flow approach, as the errors produced by the balance sheet method might have an impact on these results. The risk of estimation error can be minimised in accrual 
estimation by using the cash flow approach and can obtain unbiased results. Thus, to avoid these estimation errors, this study uses the cash flow method to calculate accruals and examine the impact of total accrual reversals on bookbased earnings. In the case of total accrual reversals, no study exists that explores the impact of reversals of total accruals on company performance. This area is totally unexplored because only a few studies discuss the reversals of current accruals and discretionary accruals, so this is a pioneering study in this regard by exploring the role of total accrual reversals. The focus of companies in emerging markets is more inclined to long-term decisions rather than short-term because companies want to retain and maintain their growth. Companies design their policies by considering the overall situation in the market as do the investors as they also focus on returns on their investments in the long run perspective. Thus, this study will try to help companies as well as investors to make their decisions by considering the reversals of total accruals in the longterm perspective. The purpose is to find the impact of the reversals of total accruals on earnings by observing the association between the reversals of total accruals and future and current earnings of non-financial companies listed on the PSE. This study explores whether these reversals affect the earnings, so that investors can make decisions by considering the relationship of total accrual reversals with company performance. Companies can also enhance their performance by knowing the impact.

\section{Literature Review}

Different studies discuss accruals and their role in earnings management. Most of the studies, like Healy (1985), Dechow (1994), and Sloan (1996), defined accruals as the product of accounting entries, which can be used to improve the capability of earnings to predict future performance. Many studies measure accruals by calculating these through the balance sheet approach. Hribar and Collins (2002) observed the impact of computing accruals from both methods, and their results reveal the existence of estimation errors in accruals measured through the balance sheet method. Hence, they suggest that it is better to use the cash flow statement approach to measure accruals directly to avoid estimation errors. As balance sheet accruals produce the problem of errors-in-variables, to avoid these errors and obtain a fair and unbiased result, this study uses the cash flow approach, i.e. Net Income Approach to measure total accruals.

Accrual considered to be reversed when the linked projected economic benefits recognised. Accrual reversals are measured as the difference between previous and current accruals. Healy (1985) identified that discretionary accruals fully reversed in two periods because they are forced to sum to zero in two periods. Accruals are more foreseen and less determined than cash flow. Teoh et al. (1998) observed the earnings and accruals behaviour in the IPO issue year and the post-issue-year, and indicated the time series pattern for accruals, which exhibit that abnormal accruals are a bit high in the issuing year and then go down and become negative in the second year. Eventually, accruals reverse and 
become insignificant with in two periods. Defond et al. (2001) specified that abnormal accruals are less persistent. Their findings are consistent with their forecast that abnormal accruals contain more estimation errors and result in a larger frequency of consequent reversals. They concluded that market participants expect the reversing inferences of abnormal accruals. These studies fail to recognise whether or not investors required information about reversals of abnormal accruals for both periods, because the availability of information is necessary to make decisions based on expectations.

The role of accrual reversals in earnings is very important. Different studies have discussed this role. Baber et al. (2011) described an empirical analysis on the reversals of discretionary accruals in the case of earnings management. Their focus was discretionary accruals that have an income-increasing pattern in the first period and then a reversing pattern in the second period. They follow an income-decreasing trend, and have negative impact on earnings. The finding recommends that the ability of reversal to meet the objective of earnings management depends on both the size and speed of past discretionary accruals reversal. Another study, by Allen et al. (2013), studied the role of reversals of working capital accruals at the company-level by categorizing the reversals as good and bad reversals in determining the earnings and stock returns. They computed accruals using the balance sheet method and calculated the accrual reversals as the difference between the current accruals and the previous accruals. The results indicate a positive association between a change in income in the current period and accrual reversals and show that extreme accruals show a high consequent reversal and that these reversals are related to the concurrent change in earnings. Extreme accruals contain a high frequency of accruals estimation error and reversals of these errors explain the lower persistence in earnings. The focus of these studies was on working capital accrual reversals and discretionary accrual reversals. Thus, a gap exists to explore the role of total accrual reversals, i.e. long-term reversals on company performance. As these studies, do not recognise the impact of accrual reversals on future earnings and fail to recognize how these estimation errors can be removed, justification is required concerning how investors can obtain benefit from accrual reversals and how companies can achieve their objective using these reversals. Justification is also needed for the reversing period of accruals and their impact on different factors like earnings and company performance, as this is missing in the literature. Thus, although potential gaps exist, this study only focuses on examining the impact of total accrual (measured by the cash flow approach) reversals on current as well as future book based earnings, which is used to measure company performance. This is a pioneering study to capture the role of total accrual reversals exclusively in company performance.

The study theorizes that total accrual reversals do not impact on earnings. As accruals need to reverse, they should be reversed in a way that has no impact on earnings. This means that the role of total accrual reversals has no significant impact on company performance. The hypothesis is 
HO: Accrual Reversals have no impact on earnings.

\section{Methodology}

\subsection{Data}

This paper concentrates on the non-financial sector of the emerging Pakistan Stock Exchange (PSE). The sample consists of 100 companies registered on the PSE. Larger market capitalization criteria are used for company selection. First, companies were selected that were consistently in the KSE-100 index while the rest were selected based on larger market capitalization. The time-period of this study is 2002-2013. The financial variables used in this study are Earnings (Earnings before Interest and Taxes), Cash Flows from operations, Long term liability, Total Assets, and Market value of Common Equity. The data of all the variables were collected from the financial statement. The variables Earnings (EBIT), Long Term Liabilities and cash flow from operations divided by Total Assets were also used by Sloan (1996) and Baloch (2015) to reduce the variation among the variables. The other variables used in the model are Size of Company (natural log of market value of equity), Growth of Company (ratio of book value of equity to the market value of equity) and Capital Structure leverage (debt to equity ratio). The following models are used to accomplish the objective. Panel data are used to estimate this model.

\subsection{Measuring accrual}

The cash flow approach is used to measure accruals as follows:

$$
\text { Accrual }=\text { Net Income }(\text { EBIT })-\text { Cash Flow from operations. }
$$

\subsubsection{Accrual Reversal}

Accrual reversal is measured as the change in accrual and is calculated as the difference between the current period $(\mathrm{ACCt})$ and the previous period $\left(\mathrm{ACCt}_{-1}\right)$ accrual.

$$
\Delta \mathrm{ACC}_{\mathrm{t}}=\mathrm{ACC}_{\mathrm{t}}-\mathrm{ACC}_{\mathrm{t}-1}
$$

\subsubsection{Accrual Reversals and Earnings}

The model illustrates that current earnings are a function of the current as well as previous accrual reversals. It also includes three control variables, which also affect the current earnings. The proposed model is partially based on the model used in the study of Allen et al. (2013).

$$
\begin{aligned}
\text { Earning }_{\mathrm{i}, \mathrm{t}}=\alpha & +\beta_{0} \Delta \mathrm{ACC}_{\mathrm{i}, \mathrm{t}}+\beta_{1} \Delta \mathrm{ACC}_{\mathrm{i}, \mathrm{t}-1}+\beta_{2} \mathrm{G}_{\mathrm{i}, \mathrm{t}} \\
& +\beta_{3} \mathrm{~S}_{\mathrm{i}, \mathrm{t}}+\beta_{4} \mathrm{CSL}_{\mathrm{i}, \mathrm{t}}+\mathrm{u}_{\mathrm{i}, \mathrm{t}}
\end{aligned}
$$

Where, Earning $\mathrm{t}_{\mathrm{t}}$ is EBIT in the current period; $\triangle \mathrm{ACC}_{\mathrm{t}}$ is the Accrual Reversal of the current period; $\triangle \mathrm{ACC}_{\mathrm{t}-1}$ is the Accrual Reversal of the previous 
period; control variables are $\mathrm{G}=$ Growth, $\mathrm{S}=$ Size and $\mathrm{CSL}=$ Capital Structure Leverage of Companies for current period.

\section{Results and Discussion}

\subsection{Descriptive Statistics}

Table 1 explains the descriptive statistics of the variables. EBIT (Earnings $t_{t}$ ) of current period, Current Accrual Reversal $\left(\triangle A C C_{t}\right)$, Previous Accrual Reversal $\left(\triangle A C C_{t-1}\right)$, Size $\left(S_{t}\right)$, Growth $\left(G_{t}\right)$ and Capital Structure Leverage $\left(C S L_{t}\right)$ for current periods. The mean of Earning $s_{t}$ is 0.239 , and the standard deviation value is 0.251 . The mean of $\triangle A C C_{t}$ is 0.004 , and its standard deviation is 0.188 . Whereas, the mean of $\triangle A C C_{t-1}$ is 0.003 with a standard deviation of 0.177 . The mean of $S_{t}$ is 9.77 , and its standard deviation is 2.077 . The mean of $G_{t}$ is -2.156 and the standard deviation value is 1.250 . The mean of $C S L_{t}$ is 0.033 , and the standard deviation value is 0.064 . The standard deviation and mean values of all the variables are close to each other.

Table 1: Descriptive Statistics

\begin{tabular}{llllll}
\hline Variables & Means & Medians & Std. Dev. & Max. & Min. \\
\hline Earnings $s_{t}$ & 0.2390 & 0.1700 & 0.2510 & 3.0500 & -0.1600 \\
$\Delta A C C_{t}$ & 0.0040 & 0.0000 & 0.1880 & 2.9800 & -3.0800 \\
$\Delta A C C_{t-1}$ & 0.0030 & 0.0000 & 0.1770 & 2.9800 & -3.0800 \\
$S_{t}$ & 9.7770 & 9.9700 & 2.0770 & 15.0500 & 2.7700 \\
$G_{t}$ & -2.1560 & 0.1090 & 1.2500 & 2.8600 & -8.0800 \\
$C S L_{t}$ & 0.0330 & 0.0100 & 0.0640 & 0.8300 & -0.5800 \\
\hline
\end{tabular}

\subsection{Correlation}

Table 2 shows the correlation values for the variables built-in in equation 1 . The correlation values among all the variables is low, which means no multicollinearity exists. Consistent with the study finding, accrual reversals for both periods have a positive association with Earningst. $S_{\mathrm{t}}$ has a positive association with Earnings $s_{t}$, which is consistent with previous findings. $C S L_{t}$ and $G_{t}$ have a negative association with Earnings $s_{t}$, which is consistent with previous results. However, it is worth noting that the correlation values do not provide a causal-effect relationship.

Table 2: Correlation Table

\begin{tabular}{lcccccc}
\hline & Earning $_{t}$ & $\Delta A C C_{t}$ & $\Delta A C C_{t-1}$ & $S_{t}$ & $G_{t}$ & CSL $_{t}$ \\
\hline Earnings & 1.0000 & & & & & \\
$\Delta A C C_{t}$ & 0.3200 & 1.0000 & & & & \\
$\Delta A C C_{t-1}$ & 0.0350 & -0.4607 & 1.0000 & & & \\
$S_{t}$ & 0.1367 & -0.0098 & -0.0054 & 1.0000 & & \\
$G_{t}$ & -0.3400 & -0.0062 & 0.0215 & -0.6035 & 1.0000 & \\
$C_{C S L_{t}}$ & -0.2647 & -0.0877 & -0.0511 & -0.0404 & -0.0091 & 1.0000 \\
\hline
\end{tabular}

\subsection{Results of Likelihood Ratio Test}

LR test

(Assumption: homo nested in hetero)

$\begin{aligned} \text { LR chi2 }(99) & =1126.66 \\ \text { Prob }>\text { chi } 2 & =0.000\end{aligned}$


The above-stated result demonstrates the existence of heteroscedasticity in the model. As the probability of LR test is significant, the null hypothesis is rejected, and the alternative is accepted, which means Hetero does exist. Thus, to tackle this problem, a robust method is needed to estimate the model.

\subsubsection{F-Test}

The F-test is applied to choose between the Fixed Effect method and Pooled Ordinary Least Squares (OLS) method. The value of the F-test is -0.2652 , which is lower than the F-critical, which is 1.2214 . Hence, the null hypothesis is accepted, which means that the Pooled OLS method is applicable. To cope with the problem of heteroscedasticity, this study used the "Pooled OLS method with Driscoll-Kraay robust standard errors." This method is suggested by Driscoll and Kraay (1998) to resolve the problems of cross-sectional dependency and heteroscedasticity in the panel nature data. This technique is adopted to tackle the problem of heteroscedasticity in the model.

\subsection{Result of regression Pooled-OLS with Driscoll-Kraay Robust Standard Errors method}

Table 3 shows the results of the Pooled-OLS Method Driscoll-Kraay Robust Standard Error regression estimation for model 1. The model estimates the impact of Accrual Reversals for both period's, i.e. current period $\left(\triangle A C C_{t}\right)$ and previous period $\left(\triangle A C C_{t-1}\right)$ on the Earnings (Earnings $s_{t}$ ) of the current period. The coefficient $\boldsymbol{\beta}_{0}$ of $\triangle A C C_{t}$, i.e. Accrual Reversals of the current period is 0.527 . This means that a $1 \%$ rise in the change in accruals for the current period will increase the current earnings by $0.52 \%$. As the probability of the t-value is significant, which is 5.35 , it means that the current period reversal has a significant and positive impact on current earnings. Thus, the null hypothesis is rejected and the other accepted. The results are consistent with the results documented by Allen et al. (2013).

Table 3: Regression Pooled-OLS with Driscoll-Kraay Robust Standard Errors method

\begin{tabular}{lllllll}
\hline & Coefficient & Std. Error & t-value & P > | t-value & 95 \% Confidence Int. \\
\hline$\Delta A C C_{t}$ & 0.53 & 0.0992 & 5.29 & 0.0000 & 0.328 & 0.722 \\
$\Delta A C C_{t-1}$ & 0.30 & 0.0968 & 3.11 & 0.0020 & 0.109 & 0.494 \\
$G_{t}$ & -0.08 & 0.0020 & -40.60 & 0.0000 & -0.087 & -0.079 \\
$S_{t}$ & -0.01 & 0.0042 & -3.37 & 0.0010 & -0.022 & -0.005 \\
$C S L_{t}$ & -0.88 & 0.1226 & -7.20 & 0.0000 & -1.126 & -0.639 \\
Constant & 0.22 & 0.0348 & 6.47 & 0.0000 & 0.1564 & 0.294 \\
\hline F value & 459.55 & & & & & \\
Probab>F & 0.000 & & & & & \\
R-square & 0.3192 & & & & & \\
\hline
\end{tabular}


This shows that when companies increase their accruals in the current period, the accruals reverse, i.e. a change in accruals happens in the current period, and, due to the increase in the accrual reversals, the cash flow decreases. However, ultimately, the current earnings of the companies increase as the earnings consist of the cash flow and accruals. Thus, a positive change in the accrual component will adjust the earnings positively. The $\beta_{1}$ coefficient of the parameter Accrual Reversals of the previous period, i.e. $\triangle A C C_{t-1}$ is 0.299 . This means that an increase in the previous period accrual reversals by $1 \%$ will increase the current earnings by $0.29 \%$. As the probability of the t-value is significant, which is 3.17 , this means that previous accrual reversals have a significant and positive impact on the current earnings so we can say that previous reversals of accrual predict the future earnings of companies positively.

The null hypothesis is rejected. This means that when accruals reverse in the previous period, which were created in the last period, this increases the cash inflow of the current period, i.e. $t-1$ as well as the next period. This is because companies keep growing their accruals due to the positive and significant reversal effect; ultimately, this also increases the earnings for the next, i.e. ${ }_{t+1}$, period. These outcomes show that companies transfer their profit from one period to the next period in the form of accrual reversals. These findings are consistent and significant with the previous findings of studies that accrual reversals of both (current and previous period) have a significant and positive impact on earnings for both periods (current and future). Thus, a change in accruals predicts the earnings positively, and, through accrual management, companies enhance their performance. An increase in accruals has a positive impact on companies' earnings.

The findings of the control variables are consistent with previously documented findings. The coefficient $\beta_{2}$ of $G_{t}$ demonstrates a negative effect on current earnings. This means that a change in the book-to-market ratio will change the current earnings in the opposite direction. This result specifies an inverse relationship between the current earnings and company growth if the BMR (book to market) ratio is used as a proxy to measure the impact of growth. The finding is also consistent with previous findings, as documented by Sloan (1996). The coefficient $\beta_{3}$ of $S_{t}$ is negative and significant, which means that an increase in size will decrease the current earnings of the company. Therefore, an opposite relationship exists between the current earnings and the size of the company. This result is consistent as documented in previous studies. Any change in size will have a negative and direct impact on current earnings. As the selected companies are the top companies, it is quite possible that any expansion will cost the companies initially.

The coefficient $\beta_{4}$ of $C S L_{t}$ specifies a negative and significant impact on current earnings. This means that the debt-to-equity ratio has an inverse relationship and increase in CSL will reduce the current earnings. When companies increases their debt financing. Their debt-to-equity ratio also increases and the financing cost, i.e. cost of debt, also increases; ultimately, their current earnings decrease. The constant $\alpha$ demonstrates, on average, a positive 
change in the current earnings, which means that if the explanatory variables included in model 1 have no role in determining the current earnings, other variables exist that determine the company performance, which are netted in the error term. As the t-value is significant, some explanatory variables are also missing in the model. These explanatory variables may be macroeconomic or company specific variables, which can determine the earnings of companies and affect their performance. However, all these variables are considered in the model and their result showed a significant impact, which helps to achieve the objective of this study.

All the variables have a significant impact on the current earnings, and the findings are consistent with the results documented in previous studies. The Rsquare shows that a $31 \%$ change in earnings is explained by the independent variables included in model 1, or that the explanatory variables explained $31 \%$ variation in the current earnings. The $\mathrm{R}$-square is low but this is normal as a low R square was observed in many studies (e.g. Jeter, 1999; Brochet, 2008; Fatma, 2012; Resutek, 2014). The value of Fstat is significant and positive, which indicates that the model is valid. These findings demonstrate the prominence of reversals of total accruals and their substantial positive impact on the earnings of companies in the long-term perspective, as reversals affect the earnings of both periods. Companies should increase their accruals, which, in return, will increase the reversals, which will increase their earnings either in the shape of an increase in the cash inflow if the change in accruals decrease, or in the shape of an increase in accruals if the change in accruals increase. If companies generate high accruals in the previous period, these will ultimately reverse in the current period as well as the next period. Thus, the earnings of companies increase in both periods, which shows an opportunity for investors. This kind of positive behaviour demonstrates the growth of companies in emerging markets. Companies are adopting these techniques to enhance their company performance. These investment opportunities attract the attention of domestic as well as foreign investors. The management of companies should pay special attention to either increase the accruals or decrease the accruals as they have a significant impact on the performance of companies. Thus, these are vital decisions for the management to smoothen company performance and to attract the investors to maintain the growth level in order to survive in the era of rivalry and competitive world.

\section{Conclusion}

This study explores the effect of reversals of total accruals exclusively on the performance of non-financial companies in an emerging market that were registered on the PSE for a period of 10 years. The performance of companies is measured by EBIT, i.e. book-based earnings. This study examines the impact of reversals of total accruals for the current and previous period on current earnings. This study uses the cash flow approach to measure accruals because of the existence of estimation errors in balance sheet accruals. The findings indicate 
a significant and positive relationship between current earnings and the reversals of total accruals for both periods. This means that when reversals of total accruals (long-term reversals) increase, it has a positive impact on earnings in the shape of an increase in cash flows, so earnings increase. The findings also reveal that current accrual reversals have a relatively more significant impact on current earnings compared to the impact of previous reversals of total accruals on current earnings. Our findings have important implications for management as well as for academics. The focus of this study is on aggregate reversals, i.e. long-term reversals. This study modelled both current and previous period total accrual reversals to explore the role in determining company performance in an emerging market more exclusively. The study also indicates the unique behaviour of companies in emerging markets. Thus, it is concluded that the role of reversals of total accruals in the performance of a company is vital. As an increase in total accrual reversals increases the earnings so companies should increase the accruals to enhance their performance. This will ultimately attract the attention of foreign investors, so they will invest more, to secure long-term investment. Thus, the management of companies should pay special attention when making decisions about whether to increase or decrease accruals because the results show the critical and significant role of these accruals on company performance. Our findings provide opportunities for future academic research. The relationship between the reversals of total accruals and company performance should be rechecked in developed markets. Good and bad reversals should be studied separately, and their impact should be differentiated. The behaviour of financial companies should be studied as commercial banks make high provision for accruals. Comparative studies may also be helpful for generalizing the behaviour of emerging markets.

\section{References}

Allen, E. J., Larson, C. R., \& Sloan, R. G. (2013). Accrual reversals, earnings and stock returns. Journal of Accounting and Economics, 56(1), 113-129.

Baber, W. R., Kang, S. H., \& Li, Y. (2011). Modeling discretionary accrual reversal and the balance sheet as an earnings management constraint. Accounting Review, 86(4), 1189-1212.

Baloch, M. S. (2015). Does the accrual anomaly exists in stock market? Evidence from Pakistan. European Journal of Accounting, Finance and Business, 3(3), 44-71.

Boubakri, F. (2012). The Relationship between Accruals Quality, Earnings Persistence and Accruals Anomaly in the Canadian Context. International Journal of Economics and Finance, 4(6), 51.

Brochet, F., Nam, S., \& Ronen, J. (2008). The role of accruals in predicting future cash flows and stock returns. Available at SSRN 1126022

Dechow, P. M. (1994). Accounting earnings and cash flows as measures of Company performance: The role of accounting accruals. Journal of Accounting and Economics, 18(1), 3-42. 
DeFond, M. L., \& Park, C. W. (2001). The reversal of abnormal accruals and the market valuation of earnings surprises. Accounting Review, 76(3), 375-404.

Driscoll, J. C., \& Kraay, A. C. (1998). Consistent covariance matrix estimation with spatially dependent panel data. Review of Economics and Statistics, 80(4), 549-560.

Healy, P. M. (1985). The effect of bonus schemes on accounting decisions. Journal of Accounting and Economics, 7(1-3), 85-107.

Hirshleifer, D., Hou, K., \& Teoh, S. H. (2009). Accruals, cash flows, and aggregate stock returns. Journal of Financial Economics, 91(3), 389-406.

Hribar, P., \& Collins, D. W. (2002). Errors in estimating accruals: Implications for empirical research. Journal of Accounting research, 40(1), 105-134.

Jeter, D. C., \& Shivakumar, L. (1999). Cross-sectional estimation of abnormal accruals using quarterly and annual data: Effectiveness in detecting eventspecific earnings management. Accounting and Business Research, 29(4), 299-319.

Lewellen, J., \& Resutek, R. J. (2014). Why do accruals predict earnings? Tuck at Dartmouth, Working paper.

Sloan, R. (1996). Do stock prices fully reflect information in accruals and cash flows about future earnings? (Digest summary). Accounting review, 71(3), 289-315.

Teoh, S. H., Wong, T. J., \& Rao, G. R. (1998). Are accruals during initial public offerings opportunistic? Review of Accounting Studies, 3(1), 175-208. 